\title{
Effects of Outsider's Monitoring on Capital Structure and Corporate Growth Strategy: Evidence from a Natural Experiment
}

July 2016

\begin{abstract}
Debt-ridden corporate growth and increased vulnerability was one of the causes of the 1997 financial crisis in Korea. Introduction of the outside director system has been the core part of the board reforms following the crisis. Our estimation using instruments obtained from a natural experiment illustrates that outside monitoring has (i) improved capital structure of firms even when we control for the leverage regulation effect (ii) enhanced compliance with leverage regulation and thus reduced business risks and (iii) reduced excessive growth and excessive investment more consistently for the top 10 largest chaebols than non-chaebol firms and smaller sized chaebol affiliates. Our results shed some light on why existing studies report the positive effect of outsiders on firm value and add value to existing agency theory by illustrating that the effect of improved governance on capital structure could be non-linear.
\end{abstract}

Key words: Corporate governance; Capital structure; Natural experiment; Growth strategy; Government regulation; Chaebol. 


\section{INTRODUCTION}

Research on corporate capital structure is extant (Rajan and Zingale, 1995; Harris and Laviv, 1991; Titman and Wessels, 1988 for references) and research on corporate governance is not a new issue either (Shleifer and Vishney, 1997 for the survey). What is relatively unknown is whether or not corporate decision on leverage is influenced by change in board structure (i.e., institutional rearrangement), particularly introduction of outside director systems in an economy where family business groups are dominant.

The board has the legal authority to ratify and monitor managerial initiatives, evaluate the performance of top managers, and reward or penalise that performance (Fama and Jensen, 1983). In addition to the traditional agency theory which emphasises the board's monitoring, Baysinger and Hoskisson (1990) claimed that the composition of boards affect corporate strategy. Some of the board's most important duties include reviewing and guiding corporate strategy, major plans of action and risk policy (OECD, 2004), and reviewing and approving corporate plans and actions (ALI, 1994). Corporate governance is defined as the whole set of legal, cultural, and institutional arrangements that determine what publicly traded corporations can do, who controls them, how that control is exercised, and how the risks and returns from the activities they undertake are allocated (Blair, 1995). Thus, the role of the board is crucial for corporate strategic decisions to manage the risks associated with leverage and growth strategy.

We observed two stylised facts from the literature on the board of directors. Firstly, much of the literature focuses on the board in general rather than on outside directors (Black and Kim, 2012, for references therein). Indeed, Nguyen and Nielsen (2010, p.550) noted that "in spite of a rich body of academic literature on the topic of boards of directors, direct empirical evidence on the value of independent directors is scant.” The importance of outside directors, 
however, is evident from government regulations on board structure and investors’ preference over a larger proportion of outside directors in board. For example, NYSE and Nasdaq regulations adopted in 1999 require audit committees to be comprised entirely of independent directors, a requirement that was extended and strengthened by SOX in 2002 (Dutchin, Matsusake and Ozbas, 2010). The Cadbury report in the UK and the Vienot reports in France all called for the greater independence of boards of directors. Coles, Daniel and Naveen (2008) state that outsider-dominated boards are preferred by investors; for example, TIAACREF, one of the largest pension funds in the world, has stated that it will only invest in companies that have a majority of outside directors on their board. The highlight of governance reforms and board restructuring following the 1997 financial crisis in Korea has been the introduction of the outside director system (Choi et al., 2007; Min and Verhoeven, 2013; Min, 2016).

Secondly, studies on outside directors have largely focused directly on the impact of outsiders on the value of firms, measured by share returns or its related variable. An increase in the proportion of outside directors in board is found to be associated with positive improvements in returns on assets and stock returns (Dahya and McConnell, 2007; Rosenstein and Wyatt, 1990), abnormal returns when tender bids are made (Byrd and Hickman, 1992), and a positive relationship with firm value, measured by Tobin Q (Choi et al., 2007; Core et al., 1999; Min and Verhoeven, 2013). ${ }^{1}$ Share returns, however, are largely determined by market investors. In particular, the relationship between firm value and outside monitoring is subject to estimation bias created by the endogeneity problem (Hermalin and Weisbach, 1998; Harris and Raviv, 2008; Titman and Wessels, 1988). For this reason,

\footnotetext{
${ }^{1}$ Min and Smyth (2014) report a positive impact of change in board structure on firm productivity.
} 
handling the endogeneity issue associated with the appointment of outside directors has become an important challenge for empirical researchers.

With this backdrop, we aim to investigate the effect of outside monitoring, proxied by the appointment of outside directors which has been the core component of board restructuring, (1) on leverage in a system framework in order to address the endogeneity problem, (2) on corporate growth and investment strategy, and (3) on the management of business risk associated with the leverage regulation. In estimations, special attention will be placed on the endogeneity of the appointed outside directors by applying a natural experiment method. Our estimation uses system framework which explicitly assumes that the appointment of outside directors is self-selective. We found excluded instruments from the unique experience of Korean firms when the government introduced a new regulation on board structure. Further, we use the difference-in-difference-in differences (DDD) method in order to check the robustness of our findings.

In addition to this, we investigated the research questions by comparing chaebol affiliates with non-chaebol firms. It is well-known that the Korean economy has been dominated by chaebols. In particular, our intra-business group analysis differs from most existing literature which handles the business groups as a whole in comparison with non-chaebol firms. Some chaebols including Samsung, Hyundai Motorvehicle, LG and SK have established their own brand image in the global market. In contrast, many smaller sized chaebols have focused on the domestic market. The amendment of the Securities and Exchange Law in 2003 following the amended Listing Act in 1998 mandated a higher proportion of outside directors for large firms, which were defined based on the size of their assets. In Korea, substantial numbers of large firms are chaebol affiliates. The average size of chaebol affiliates, measured by their natural logarithm of assets in 1000 Korean Won, during our sample period was 21.43 compared to 18.97 for non-chaebols (refer to Table 1). As a result, chaebol affiliates have 
been forced to appoint a greater number of outside directors to board members (refer to Table 1).

A greater portion of outside directors to board members usually translates to strengthened outsider monitoring. Joh and Jung (2011) reported a positive association of outside directors who have relationships with CEOs with a positive value of firm. Lee (2015) also claimed the positive effect of outside directors based on her empirical finding of the increase in the sensitivity of inefficient CEO turnover to performance when board regulation to incorporate outside directors strengthened. ${ }^{2}$ In addition to this, chaebol affiliates have better opportunities to appoint qualified outside directors to monitor their board's decisions than non-chaebols due to their better payments and social reputation as a working place. ${ }^{3}$ Large firms including chaebol affiliates also draw more attention from media and market analysts. As such, outside directors' activities of chaebol affiliates have been more publicised than non-chaebols. This publicised information is a pressure for outsiders to reflect expectation from the public and criticism from the academics. For these reasons, we expect the effect of outsider monitoring on capital structure and corporate growth strategy differs between chaebols and non-chaebols.

In summary, in contrast to existing studies which focus on the effect of outside directors and board reforms on financial variables (i.e., firm value), our study investigates the effect of outsider’s monitoring on corporate risk management (i.e., capital structure and compliance of

\footnotetext{
${ }^{2}$ Prior to this reform, virtually no Korean firms had outside directors. There has also been criticism about the effectiveness of outside director systems in Korea by pointing out low rejection rates in board meetings partly due to the outsider's personal relationship with the CEO and the possibility of replacement when outsiders vote against the management plans (Kim and Lee, 2015). A counter argument to this criticism is that management teams usually communicate with outsiders prior to board meetings to avoid official conflicts and thus the low rejection rates do not measure the effectiveness of the system (from the author's conversation with multiple scholars who are working as outside directors). People in favour of the system also add that the existence of outsiders itself is a pressure to management. We notice existing arguments are somewhat impressionistic without any rigorous analysis. As such, this controversy also justifies our study which is based on samples from (virtually) all listed companies.

${ }^{3}$ Similarly, university graduates prefer chaebols to non-chaebols for their jobs. Because of this high demand the annual job-entry examinations organised by chaebols such as Samsung have been regarded as one of the hardest tests in Korea.
} 
regulation) as well as corporate growth and investment strategy between chaebols and nonchaebols. For this reason, our finding is expected to add value to capital structure literature as well as shed light on channels between the appointment of outside directors and firm value. Our main finding is that improved outsider monitoring leads to lower leverage from all firms even when we account for the effect of leverage regulation, and greater compliance with leverage regulation, thus reducing business risks associated with regulation, particularly from chaebol affiliates. A further analysis indicates that the positive effect of outsider monitoring on excessive growth and investment is consistently observed for chaebol affiliates, particularly for the top 10 largest chaebols.

\section{DEVELOPMENT OF HYPOTHESES}

Corporate strategies such as capital structure and important investments are the board's decisions. The role of outsider's monitoring has become more important in board decisions particularly from the 1997 Asian crisis and the advent of SOX in 2002. The appointment of outside directors is a result of rearrangement of a (legally-binding) institutional setting, which creates different research environment from the traditional capital structure theories evaluating costs and benefits using financial statement information (Rajan and Zingale, 1995; Harris and Laviv, 1991; Titman and Wessels, 1988; Myers and Majluf, 1984) ${ }^{4}$.

There are two conflicting views on the effect of board reforms through appointment of outside directors on capital structure. On one hand, the positive effect of outsider monitoring on leverage is from the perspective of suppliers of capital (La Porta et al., 1997). Improved governance means strengthened protection of minority shareholders (Shleifer and Vishney, 1997). An increase in monitoring strengthens the protection of lenders, whereby lenders

\footnotetext{
${ }^{4}$ The financial statement information includes tax shields (debt and non-debt tax such as corporate, personal and non-debt related taxes such as tax deduction for depreciation and investment tax credits), growth, profitability, size, earnings volatility, industry classification and asset structure (i.e., collateral value of assets).
} 
required returns decreases to the extent that the protection affects systematic risks. That means a reduced cost of external financing to borrowers. Mclean et al., (2012) found external finance increases more strongly with investment opportunities in a country with strong investor protection. The pecking-order theory of financing, which is based on the view that information asymmetries between new investors and managers who maximise the wealth of existing shareholders make equity issues more costly than debt issues, indicates debt financing should dominate equity financing (Myers and Majluf, 1984). This is because issuing debt secured by assets with known collateral value avoids the costs associated with asymmetry between managers and outside shareholders. Without collateralised assets, lenders require more favourable contract terms for debt covenant which leads firms to use equity finance.

Further, improved monitoring lenders facilitates management goal to be congruent with shareholder's goal, which is a crucial assumption for the pecking-order theory (Dybvig and Zender, 1991). The pecking-order theory, coupled with the positive effect of monitoring on accessibility of external financing, implies improved governance will lead to high leverage. Empirical results support this positive effect of improved governance on leverage (Coles, Daniel and Naveen, 2008; Giannetti, 2003). However, one of the limitations of this lender's channel argument is that the role of change in board's monitoring becomes irrelevant when firm has few valuable investment projects and does not demand for external funds.

In contrast to this lender's channel, we notice that improved governance can decrease leverage through modifying borrower's channel particularly when firms have few profitable investment opportunities. Both the agency theory (Jensen and Meckling, 1976; Jensen, 1986) and the debt-overhang hypothesis (Myers, 1977) imply that improved governance should motivate management to re-evaluate risk management and choose conservative capital structure particularly when firms do not have sufficient good investment opportunities. 
Existing theories suggest improved governance can substitute the role of high leverage to mitigate manager's private consumption and perquisites because of the increased threat of bankruptcy and lender’s (i.e., bondholders) monitoring to prevent bankruptcy (Grossman and Hart, 1982) and the manager’s limited control over firm’s (free) cash flows (Jensen,1986; Stulz, 1990; Easterbrook, 1984). That means an inverse relationship between monitoring and leverage. The debt overhang hypothesis (Myers, 1977), which predicts under-investment problem arising from pre-existing defaultable debt and agency problem between shareholders and bondholders, implies that low leverage is desirable particularly when firms expect profitable projects in the future.

The debt overhang hypothesis, combined with the effect of improved governance on borrower's channel, is directly relevant for firms who experienced financial crisis for two reasons. Firstly, profitable projects should be scant during and/or following a financial crisis. For this reason, other things being equal, outsider's monitoring constrains management's borrowing which might be used for non-profitable projects but building a business empire (Jensen, 1986; Easterbrook, 1984). Secondly, firms who experienced financial distress are expected to be more aware of risk management. Rajan and Zingales (1995) proposed that management has a strong incentive to pursue conservative capital structure because they want to avoid any penalties by the strengthened board power when firm improves governance system. This penalty includes replacement of the management. The static trade-off argument in finance implies the importance of the net effects of leverage. Board members (i.e. borrowers) need to consider not only positive tax-saving effects of interest payments but also expected deadweight loss in default. Such increase in risk is particularly prominent during a crisis. The 'cold-shower' effects of financial distress during a crisis can lead monitoring to focus more on negative risk factors. 
The experiences of the 1997 Asian financial crisis and subsequent government-initiated reforms in Korea highlighted the importance of board's monitoring through the appointment of outside directors (Choi, et al., 2007; Min and Verhoeven, 2013; Min, 2016). Existing studies report that corporate governance system prior to the 1997 crisis failed ( $\mathrm{Li}, 2003$; OECD, 2003; Mitton, 2002), particularly with regard to monitoring debt-ridden growth strategy and tunnelling by controlling shareholders (Bae et al., 2002; Joh, 2004; Krueger and Yoo, 2001). As such, corporate governance system has been substantially changed with a view to strengthening the monitoring function of the board. The core of the reforms has been the amended Listing Act of 1998 which requires no less than 25 percent of the board members of listed firms to be outside directors (Black and Kim, 2012; Choi et al., 2007; Min, 2013).

Further, as outlined in the introduction section, chaebols vis-à-vis non-chaebols have a better chance to strengthen outsider's monitoring as they have been required to appoint more portions of outsiders to boards and because of their better capacities to appoint qualified outside directors. Due largely to attention from media and business analysts, outsider's activities from chaebols are more available to the public than non-chaebols which in turn create a pressure for chaebol outsiders to improve their monitoring. We therefore hypothesize:

H1: In a Korean context, an increase in outsider monitoring decreased corporate leverage. H1_A: The negative effect of outsider monitoring was more relevant for chaebols than nonchaebols.

Corporate risks include risks resulted from excessive leverage as well as business risk associated with government regulations (Schwartz-Ziv and Weisbach, 2013). In addition to board reform, the Korean government imposed regulations on corporate leverage following 
the 1997 financial crisis, which is an unprecedented case. The government requires a firm's leverage, defined as total debts scaled by book value equity, to be below 200 percent to alleviate criticism that excessive debt-ridden investment and increased vulnerability had caused the 1997 crisis (Kawai et al., 2000; Stiglitz, 2001). While theoretical validity of the 200 percent leverage ratio is questionable, we expect that the effect of the financial crisis and experience of financial distress motivated outside directors to be more concerned about corporate risk management.

Existing studies attributed highly indebted growth strategy prior to the 1997 financial crisis, particularly from chaebols, to increased vulnerability of the economy to external shocks (Joh, 2004; Krueger and Yoo, 2001). Joh (2004) reports that the average debt-equity ratio of Korean firms has been very high for a long time before the crisis and Korean firms' average debt-equity ratio in 1997 was 396 percent, which was higher than those of other countries' (United States, 154 percent; Japan, 193 percent; and Taiwan, 86 percent). Further, most of these firms adopting growth strategy failed to improve financial performance. These studies imply that debt-ridden growth before the crisis, particularly for chaebols, was excessive and inefficient. ${ }^{5}$ The growth strategy before the crisis was a result of the belief that 'too big to fail’ dogma. Chaebol affiliates could access debt market easier than non-chaebol firms given the tradition of collateral-based lending from banks. Until the introduction of the reforms following the 1997 crisis, chaebol affiliates enjoyed the increased collateral values for borrowing through mutual guarantee for debt payment among the affiliates. This debt-ridden growth from chaebols was protected from risk of bankruptcy due largely to political reasons such as to minimise negative impact associated with large unemployment and this in turn led to the prevalent belief of 'too big to fail'. Leverages of sixteen out of the thirty largest

\footnotetext{
${ }^{5}$ Chaebol has been a contentious issue in Korea in many aspects. Refer to Moskalev and Park (2010) for chaebol's value-management, Song and Han (2015) for stock market reaction to corporate crime, Oh et al.(2011), Ahn and Park (2016), and Chang, Oh and Park (2015) for corporate social responsibility.
} 
chaebols were higher than 400 percent in 1996. In addition to the collapse of Daewoo, highly leveraged chaebols were subjected to bankruptcies such as Hanbo, Sammi, Jinro, Daenong, Hansin and Kia Motor.

However, the experience of the financial crisis has created a 'cold shower' effect and a momentum for managers to realise the importance of risk managements. Indeed bankruptcies of financially distressed firms have been determined by market forces rather than political reasons irrespective of the size of the firms. Having noticed the side-effects of the chaebols' debt-ridden growth and the belief of 'too big to fail' dogma, Korean government initiated the reform of chaebols as the highest priority following the crisis (Min, 2016). The core parts of this chaebol restructuring program include improvement of capital structure and prohibition of mutual guarantee for debt payment among affiliates. For this reason, we hypothesize:

H2: Outsider's monitoring positively impacted on the compliance of the leverage regulation. H2_A: The positive impact of monitoring on the compliance of the leverage regulation was more relevant for chaebols than non-chaebols.

The free cash flows theory indicates entrenched managers and controlling shareholders can use the borrowings to build a business empire (Jensen, 1986; Easterbrook, 1984). The debtoverhang theory (Myers, 1977) also implies that improved governance should motivate management to choose conservative capital structure. Existing studies reported that poor governance is associated with less efficient mergers and acquisitions (Lewellen et al., 1985; Masulis et al., 2007). In contrast with this 'bought investment', the effect of governance on 'built investment' (i.e., conventional investment) has been controversial and requires further research (Billett et al., 2011). A positive association between poor governance and greater industry-adjusted investment was reported by Harford et al., (2008) and Richardson (2006), whereas a negative association by Bertrand et al. (2003) and Giroud et al. (2010). 
In principle, the "quiet life” argument implies that strengthened governance prevents either manager's under-investment (i.e. quiet life) by improved monitoring or over-investment by curbing manager's plan to build a business empire. Taken into consideration academic findings that debt-ridden and poorly returned investments for compressed growth policy was one of the causes of the 1997 crisis (Krueger and Yoo, 2001; Joh, 2004), the Korean government considered rectifying the market's belief of 'too big to fail' dogma and curbing the chaebol's debt-ridden growth strategy as an urgent goal. To achieve this goal, the government aimed to reform the large chaebols by (i) improving transparency of management, (ii) business specialisation and (iii) strengthening legal responsibility of controlling shareholders. In particular, the policy of business specialisation is to remove overlapping (excessive) investments among the large chaebols through 'big-deals'. 'Big deals' means the government-initiated 'give-and-take' style of exchanging affiliates among the large chaebols in order to avoid over-lapping/excessive investments in an industry. Secondly, the government encouraged the rest of chaebols' reform through a work-out program which emphasised a bank-initiated voluntary restructuring of the financially distressed firms. ${ }^{6}$ For this reason, we hypothesize:

H3: Outsider's monitoring following the restructuring of the economy attenuated the existing growth-oriented policy.

H3_A: The attenuation effect on the growth-oriented strategy was more relevant to large chaebols than smaller chaebols.

\section{METHOD}

\footnotetext{
${ }^{6}$ As at the end of June 1998, 104 firms which include 12 affiliates of the bankrupted Daewoo group were selected for the workout programs.
} 
The appointment of outside directors is typically self-selective to the extent that appointments are motivated by the expected benefits of such appointments (Hermalin and Weisbach, 1998). We utilise instrument variable estimation to address endogeneous problems associated with governance variables.

Listed firms started to appoint outside directors since the amendment of the Listing Act in 1998. Despite the regulation which requires the portion of outsiders in board to be at least 25 percent, it has not been complied by all listed firms (Min, 2013, 2014). This partial compliance of the regulation suggests the self-selection problem. Self-selection refers to a situation where firms appoint outside directors when this appointment is believed to affect the response variable. For example, a firm may appoint outsiders expecting the appointed outsider's monitoring will decrease or increase the leverage. This self-selection violates the assumption of randomness of included covariates in regression and causes an inconsistency of the estimated coefficients. The main specification has the following system equations.

$Y_{i j t}=$ const $+\delta$ Outsider's $_{\text {Monitoring }}+\beta X_{i t}+$ Industry $_{j}+$ year $_{t}+\varepsilon_{i j t}$

Outsider's Monitoring $_{i j t}=\alpha+\pi_{1} X_{i t}+\pi_{2}$ Excluded $_{\text {Instruments }}$

$$
+ \text { Industry }_{j}+\text { year }_{t}+u_{i j t}
$$

Where, the subscripts $i$ and $t$ refer to firm and year rank respectively. In structural equation (1) $Y_{i j t}$ is the response variable and Outsider's Monitoring is the main regressor, which is a response variable in the reduced-form equation (2).

Conditional on the validity of the instrument, $\delta$ captures a causal (marginal) effect of outside directors' monitoring on the response variables. $X_{i t}$ is a set of time-varying standard control variables commonly used in the literature. Using 10 countries database including Korea, 
Booth et al., (2001) found major determinants of investment in developing countries which are similar to developed economy include size, returns on assets, market-to-book ratio, tax rate, business risk and asset tangibility. Regressors included in our estimation are largely based on these variables and are dependent on model specifications. A full set of year and 3digit KSIC industry (j) dummies are also used to account for time fixed effects including the regulation effect during our sample period and industry-specific time-invariant effect respectively. All standard errors (p-value) are obtained after accounting for clustering effect at firm level.

In view of our research goal, we use the proportion of outside board members as a proxy for Outsider's Monitoring. Researchers have commonly used the proportion of outside directors of total board members as a proxy for monitoring intensity of outside directors (Coles et al., 2008; Rosenstein and Wyatt, 1990). As described above, however, the outsider variable creates an endogeneity problem. As such, we need instruments that are obtained through the following identification strategy.

\section{Identification strategy}

The identification assumption of the instrument estimation is that, conditional on the included regressors, the instruments do not affect the response variable independently of the change in the ratio of outside directors to total board members. Considering the difficulty in finding quality instruments, existing studies suggest finding instruments through the natural experimental nature of reforms (Ahern and Dittmar, 2012; Angrist and Pischke, 2009). We instrumented the appointment of outside directors using the board size of firms before the implementation of board regulation. The amended Listing Act following the 1997 crisis in Korea requires all listed firms to appoint outside directors to at least 25 percent of board positions. To comply with this ratio (i.e. outside director/board member), firms should either 
increase the number of outside directors (i.e. numerator) and/or reduce board size (i.e. denominator). That is, the size of the board before the implementation of the regulation will be considered when firms appoint outside directors. ${ }^{7}$

Relationship between board size and firm performance has been controversial. Some empirical studies suggested a negative relationship between board size and firm performance (Yermack, 1996), supporting the hypothesis of communication and coordination problems (Lipton and Lorsch, 1992; and Jensen, 1993). In contrast, Coles et al. (2008) reported a positive effect of board size on firm value, particularly for large firms, supporting the hypothesis that board size is determined by firm characteristics. We expect board size has no positive impact on firm performance in Korea as existing studies indicate a failed board function prior to the 1997 crisis (Li, 2003; OECD, 2003; Mitton, 2002; Bae et al., 2002).

All our estimations are based on the 2SLS method where the estimation of outside monitoring is done first and then the projection of this estimate is used to estimate our main response variables in the second stage (with a proper adjustment of standard errors by STATA/MP 14). In addition to the natural experimental method instrument, we also use the 2SLS in conjunction with the regression residual method and the difference-in-difference-indifference (DDD) method for the robustness check. Another method to obtain the instrument is to use regression residuals. This residual method is to mitigate reverse causality arising from the direction of causality which is from outcome variables, such as leverage and excess investment, among others, in our main regressor variable (i.e., outsider monitoring). Consider

\footnotetext{
${ }^{7}$ Subsequently amended laws including the Securities and Exchange Law require firms to increase the ratio of outside directors to total board members if the size of their assets is large. This condition also suggests that the size of assets of a firm mattered when board reforms were introduced. However, we did not consider the size of assets for the excluded instruments because asset variable is one of the included regressors.
} 
a situation where excessive investment increases when the size of a firm increases due to the belief of 'too big to fall' dogma and this rising investment causes more appointment of outside directors due to required more amount of monitoring. Residuals are obtained from the regression of outside directors on asset. This instrument adjusted for firm's assets would satisfy the assumption of instrument variable method by construction (Amiti and Weinstein, 2011). We will explain this method further in our robustness check section shortly.

DDD is an improvement of the difference-in-differences method which has been widely used to examine the effect of policy reforms (Wooldridge, 2010; Gruber, 1994). Indeed, the appointment of outside directors (i.e., outside monitoring) has been forced by a new regulation in Korea. One of the advantages of the DDD is that researchers can avoid the challenge of finding valid instruments. We will explain this method in detail shortly in our robustness check.

\section{Data}

We obtained data from the Korea Listed Companies Association (KLCA) database, combined with KIS line, which have the most comprehensive coverage of listed companies on the Korea Exchange. Our sample covers the period from 1998, when the KLCA database began to publish information about outside directors, through to 2014.

Table 1 show that average (median) outsider monitoring, proxied by the ratio of outside director to board member, was 0.327 (0.333). Average board size in our sample period was around 6 and this is one smaller than the board size in 1998 (i.e., baseline year for our identification). The last three columns in Table 1 suggest that the average board size of chaebols is one larger than non-chaebols. The portion of the appointed outside directors in board members for chaebols (0.31) is higher than non-chaebols (0.28). 
Table 1 also reports that the average leverage of chaebol affiliates (84.28) is greater than nonchaebols (68.69). The average growth rate, measured by increment of assets divided by onelagged assets, is 7.24 percent and there is no statistical difference between chaebol affiliates and non-chaebol firms. The investment growth rate, calculated by increment of property, plant and equipment (PPE) divided by one-lagged PPE, is also similar between chaebol affiliates and non-chaebols. Calculation of share returns and other firm characteristics including Tobin Q, assets, earnings and firm age is based on the standard method. ${ }^{8}$

Leverage $<200$ refers to a binary variable that equals to unity if a firm's leverage in a particular year is below 200 percent, and zero otherwise. The last column reports a larger portion of average non-chaebol firms than chaebol affiliates have leverage below 200.

We classified chaebols in this paper based on our database. Firstly, we considered a firm which has a name of group-company as candidate for chaebol affiliate. Then, we aggregated the assets of all affiliates within the same name of group-company each year. Finally we ordered each business group according to their three-year average size of assets in 2000, 2005 and 2010. We found the binary variable for chaebol defined as the Korea Fair Trade Commission is most similar to the top 20 largest chaebol in our definition. The advantage of our classification vis-à-vis the KFTC is that we can investigate intra-business group difference which is different from existing studies. Existing studies on Korean economy use a binary variable to distinguish only between chaebol and non-chaebol and ignored intrabusiness group differences if any. We used this top 30 chaebols interchangeably with chaebols unless states otherwise.

\section{***** Table 1. Summary statistics}

\footnotetext{
${ }^{8}$ Alternative measure of earnings is to use cash flow net of interest expenses. However, this variable may proxy for a firm's capital structure rather than for the availability of internal funds (Lang, Ofek and Stulz, 1996).
} 


\section{RESULTS}

Table 2 reports the negative impact of outside directors' monitoring on firm leverage as expected. The results show that outside directors' monitoring intensity, adjusting for other included regressors, reduces leverage irrespective of sample restrictions and different combinations of excluded instrument variables. Dependent variable is in logarithm and thus the estimated coefficients represent semi-elasticities. The statistically significant estimated monitoring semi-elasticity (in absolute term) ranged between 0.014 and 0.032 for unrestricted models (1) - (3). This indicates that a unit increase in monitoring, proxied by the fraction of outside directors in board members, causes a reduction in leverage by 1.4-3.2 percent. This means the monitoring effect on leverage is economically significant. This finding is a supportive evidence of Hypothesis 1.

In column (1), the excluded instruments include baseline board size multiplied by year dummies and it's squared. For robustness check, we also used the excluded instruments using only the baseline board size multiplied by year dummies in column (2). Estimated coefficient of outsider monitoring showed consistently negative result.

To examine whether the effect of outsider monitoring on leverage differs between chaebol affiliates and non-chaebol firms, we split the sample as indicated in columns (3) and (4). The results show both chaebols and non-chaebols have negative impact. However, the estimated coefficient of non-chaebol is not statistically significant and only chaebol is significant. This is a supportive evidence of hypothesis H1_A.

A remaining concern is estimation bias due to the confounding effects from the 200 percentage leverage regulation which was introduced almost concurrently with the introduction of outside director system. To minimise this confounding, we firstly explicitly 
included time-effects in all our model specifications. The introduced leverage regulation requires all firms whose leverage ratio is greater or equal to 200 percent to reduce to below 200. This ensures the estimated coefficient of outsider monitoring is based on (within) variation at each firm-cell, adjusting for macro-level shocks (including the leverage regulation) and other observed regressors.

In addition, we split the sample as in columns (5)-(7) by creating a binary variable equal to unity when a firm's leverage is below 200 and zero otherwise. The rationale behind this splitting sample is that a firm whose leverage is below 200 at a year point in time is not subject to the leverage regulation. As a result, the estimated coefficient of outsider monitoring is free from the confounding led by the leverage regulation. Results in columns (5)-(7) confirm the negative impact of outsider monitoring on leverage from the unrestricted models.

This finding implies that improved monitoring by the appointed outside directors motivated management to improve capital structure following the 1997 financial crisis in Korea, although the existence of the optimal level of capital structure has been controversial. As the agency theory suggests, an improvement of governance could have facilitated firm's external financing. This is because lenders prefer strengthened corporate governance. Leverage would increase to the extent that borrowing from banks increase faster than equity financing. Our results, however, support the negative impact of improved governance on leverage controlling for investment opportunity. That is, the results in Table 2 illustrate that, given the level of investment opportunities and profitability, the strengthened outsider monitoring following the experience of financial crisis and financial distress resulted in decreasing leverage. 
Estimated coefficients of included control variables are as expected. Estimated signs of TobinQ and firm size (i.e., Asset) means are positive, indicating that firm increases leverage to capitalise profitable investment opportunities and collateral values. The large size of firm also indicates a less asymmetric information problem to lenders which in turn facilitates firm's borrowing. In contrast, the estimated sign of profitability (i.e., Earning) is negative. The pecking order theory of financing implies that a higher level of profits increases internal financing and thus reduces external financing. The lower panel of columns (1) and (2) reports the robustness information of the instrument variable estimation. $\bar{R}^{2}$ and partial $\bar{R}^{2}$ are from the first stage estimation. The F-test (p-value) is for the null hypothesis of simultaneous zeros of the excluded instruments in the first stage estimation.

\section{***** Table 2. Impacts of outside directors' monitoring on leverage}

To examine the effects of monitoring on compliance with the leverage regulation, we first identified firms whose leverage was higher than 200 percent in 1997. We then generated a series of binary variables which are equal to one if a firm complied with the regulation in a given year and zero otherwise. For example, $Y_{97 / 01}\left(Y_{97 / 03}\right)$ represents a binary variable that is equal to one if a firm's leverage in 1997 was higher than 200 but dropped below 200 percent in 2001 (2003). The same method is applied to the rest of the response variables up to the year 2006, when the average ratio was stabilised and maintained without much changes (refer to Appendix 1).

In our MLE estimation of the outsider monitoring on the compliance of the leverage regulation, the structural equation (1) described above needs to be changed to equation (3) below in order to reflect the non-linear characteristic response variable. We assume the 
probability of observing the response variable $Y_{i t}$ in the structural equation (3) follows the standard normal cumulative distribution function.

$Y_{i t}=\left(\begin{array}{l}1 \text { if } \quad Y_{i t}^{*} \geq 0 \\ 0, \text { otherwise }\end{array}\right.$

Where, $Y_{i t}^{*}=$ const' $^{\prime} \delta^{\prime}$ Outsider's Monitoring $_{i t}+\beta X_{i t}+$ year $_{t}+\varepsilon_{i t}$.

Table 3 shows that estimated coefficient of outsider monitoring in both all sample and chaebol affiliates are positive and significant at conventional level. This is a supportive evidence for Hypothesis 2 which states a positive impact of outsider's monitoring on the reduction of business risk. The observed response variable represents the decisions of firms whose leverage was higher than 200 in the baseline year of 1997 but dropped below 200 percent sometime between 1999 and 2004.

In contrast with chaebol affiliates, the compliance of leverage regulation led by improved outsider monitoring for non-chaebol firms was negatively significant. This result supports Hypothesis 2_A.

\section{***** Table 3: Effects of outsider monitoring on compliance with the 200 leverage regulation}

To investigate our hypothesis 3 stating a negative impact of outsider's monitoring on growthoriented strategy, we estimated the effect of outside monitoring on (total) growth rate and investment growth rate in sequence.

Results on columns 1 and 2 in Table 4 report the effect of outsider monitoring on firm's excess growth rate is negative as indicated by Hypothesis 3. This negative impact was true 
only for chaebol affiliates, supporting Hypothesis 3_A. We assume industry mean value of growth proxy a potential growth trend. Following the tradition of the KLCA database, we define growth as increment of asset divided by asset in the previous year. Asset growth rate is one of the most popularly used for growth indicators in Korea.

Results in Table 4 illustrate that an improved outsider monitoring following the 1997 financial crisis led to corporate downsizing particularly for chaebol affiliates.

\section{*****Table 4. Instrumental variable estimation of the impact of outsider monitoring on excessive growth.}

Further, we examined in Table 5 the effect of outside monitoring on excess investment. Investment growth rate is calculated by the change in property and plant and equipment (PPE) over the two periods divided by the lagged value of the PPE. Excess values are

calculated by the same method as in Table 4. Correlation between the two dependent variables in Table 5 was 0.38 with statistical significance at conventional level.

Interestingly, results illustrate that outsider monitoring decreased chaebol affiliate's excess investment growth. In contrast, the effect of outside monitoring for non-chaebol was not statistically significant. These results are in line with our finding for excess growth in Table 4 above.

*****Table 5: Effects of outsider monitoring on excess investment $* * * * *$

\section{Further analyses and robustness checks}

Having observed that the effects of outsider monitoring on leverage, compliance with leverage regulation and corporate downsizing is significant we split chaebol affiliates into 
top10 largest chaebols and the next 11-30 largest chaebols. Table 6 reports that the effect of outsider monitoring on leverage differs between top 10 largest and top 11-30 chaebols. Result in column 1 reports that the impact of outsider monitoring on leverage were negative for all chaebols. However, results of the split chaebols confirm in columns 2 and 4 that only top 10 largest chaebols had persistent negative impact of outsider monitoring.

This finding may imply that the effectiveness of outside directors on leverage is significant only for largest chaebols but not for smaller sized chaebols. It is well known that controlling shareholders of chaebol have strong power over managerial decisions regardless of her/his legal responsibility. However, largest chaebols have relatively been exposed more to media attention and NGO activists than smaller ones, particularly since the onset of the financial crisis. As a result, the appointed outside directors could have had more pressure to actively monitor leverage for the largest chaebols. The amended Securities and Exchange Law also required more portion of outside directors in board members than non-chaebols, which intensified the outsider's monitoring.

\section{***** Table 6. Intra-business group difference of the effect of outsider monitoring on leverage}

We also investigated the effect of outsider monitoring on share return and found that market evaluated positively top 10 largest chaebols' reducing excessive growth rate and corporate downsizing, though top 11-30 largest chabeols did not gain market's positive evaluation of the firm's share due possibly to the ineffective outsider monitoring to reduce leverage and curb corporate growth strategy (not reported). This positive effect of outsider monitoring on share return is consistent with existing studies mapping outsider monitoring positively to firm value. We also found that the negative impact of outsider monitoring on excessive growth rate and investment is robust irrespective of controlling for the uniqueness of Korean 
financial market system (not reported). We investigated the effect of outsider monitoring on excessive growth rate for movers, where mover is defined as a firm experiencing decreasing leverage from equal to or above 200 percent in 1997 to below 200 in a year between 2001 and 2006. We found similar results using the excessive investment (not reported).

We have utilised a natural experiment of policy change to obtain excluded instruments. In addition, Amiti and Weinstein (2011) demonstrated another way to find excluded instrument from regression residuals. Following their rationale and for a robustness check, we considered reverse causality arising from the size of firm affecting both excessive growth rate and appointment of outside directors. To address this reverse causality, we a la Amiti and Weinstein (2011) use the residuals from a regress of outsider monitoring on (log) asset as an instrument. These residuals are found to be uncorrelated with the excessive growth rate but correlated with the outsider monitoring by construction. Results indicate our main findings are intact even when we use instruments obtained from regression residuals (not reported). We found similar results using excessive change in investment as dependent variable albeit the efficiency of estimation dropped substantially (not reported).

To investigate further the impact of compliance with the leverage regulation as a robustness check, we first consider the following Difference-in-difference-in-differences (DDD) model specification. To apply this DDD method, we take the regulation on board structure as the policy variable. The amended Listing Act 1998 requires all listed firms should appoint outside directors as no less than 25 percent of board members. We call treatment group as a firm (i) belonging to the compliance of this board regulation and control groups for the rest of the firms. That is, the treatment group for the outsider regulation (i.e., treat(outsider)) is indicated by a binary variable function $1[i \in$ Treat(outsider) $]$, where 1 is equals to unity if the conditions within [.] are satisfied and zero otherwise. For example, the first 1 equals to unity 
if a firm (i) belongs to the treatment group (Treat(outsider)) which refers to firms complied with the 25 board regulation, and zero otherwise.

We examine the effect of the treatment on leverage by splitting the sample period before (i.e., $t=$ before:1997-1999) and after ( $t=$ after: 2001-2003) periods. In our estimation, we averaged all time-varying variables for the 1997-1999 and 2001-2003 periods in order to be in line with the spirit of difference-in-difference (DID) method. The idea of this DID method is to compare outcome variables of firms who complied with the regulation with its counterfactuals which are proxied by non-complied (similar) firms in the post-period.

However, the estimates by DID are biased if there is any other (unobserved) trend which systematically affects the outcome variable (Gruber, 1994). Indeed, Korean listed firms have experienced leverage regulation during our sample period. In our estimation, the DID estimates will be biased if a firm more actively complies with legal requirements of the leverage regulation than another firm who passively reacts to regulations. The estimation bias will be larger to the extent that this corporate strategy to react to regulations affects the firm's compliance with the 25 percent board regulation in different ways. Firm's willingness to comply with statutory requirements can confound the estimates for the treatment effects estimated by DID. For example, firms complied with leverage regulation have a tendency of being better legally mindfulness and this in turn affects the firm's appointment of outside directors. Without addressing this difference in legal-consciousness, therefore, the estimation of the treatment effect on leverage will be biased. Thus, we created another binary variable to indicate the treatment group for the leverage regulation (i.e., treat(leverage)) by the same method as for the board regulation. $1[i \in$ Treat(leverage) $]$, where 1 equals to unity if the conditions within [·] are satisfied, and zero otherwise. For example, the first 1 equals to unity if a firm (i) belongs to the treatment group (Treat(leverage)) which refers to firms compling 
with the 200 percent leverage regulation, and zero otherwise. We observe that Korean government introduced a statutory requirement for all listed companies to appoint outside directors for at least 25 percent of board members following the 1997 financial crisis. In reality, however, not all listed firms have complied with the board reform regulation. We expect a firm who complied with this 25 percent outsider regulation ( $i \in$ Treat(outsider)) be impacted differently by the leverage regulation than another firm. To eliminate the confounding arising from this corporate strategy toward compliance with regulations, we use the following difference-in-difference-in-differences (DDD) method.

$$
\begin{aligned}
& Y_{i t}=\text { const }+\psi 1[i \in \text { Treat }(\text { outsider })] \times 1[t \in \text { after }]+\eta_{\text {od }} 1[i \in \text { Treat }(\text { outsider })]+ \\
& \eta_{\text {lod }} 1[i \in \text { Treat }(\text { leverage })] \times 1[i \in \text { Treat }(\text { outsider })]+ \\
& \Delta 1[i \in \text { Treat }(\text { outsider })] \times 1[t \in \text { after }] \times 1[i \in \text { Treat }(\text { leverage })]+ \\
& \eta_{\text {leverage }} 1[i \in \text { Treat }(\text { leverage })]+\theta 1[t \in \text { after }]+\delta 1[i \in \text { Treat }] \times 1[t \in \text { after }]+ \\
& +\mathbf{\beta x}_{i t}+\varepsilon_{i t}
\end{aligned}
$$

Where, Treat (leverage) refers to a binary variable which equals to unity if a firm belongs to the treatment (i.e., complied with) for leverage regulation. Treat (outsider) also refers to a binary variable for the 25percent outside regulation. The estimated coefficient of the triple interaction, $\Delta$, captures the impact of the compliance with the leverage regulation. This coefficient $\Delta$ is the estimate controlling all confoundings arising from group-specific and time-specific trends as well as systematic differences led by tendency of complying statutory requirements.

We consider year 2000 as the dividing year because the grace period given to firms was until the end of 2000. $\mathbf{x}_{i t}$ are a vector of control variables to capture differences in firm's initial conditions. We included three control variables including logarithm of assets, earnings (scaled by assets) and firm age. Assets and earnings variables are two lagged variables to minimise reverse causality. 
Table 7 reports DDD estimates for the impact of board regulation on capital structure. Our main interest is the coefficient $(\Delta)$ of triple interactions, Treat(outsider)XTreat(leverage)Xafter(scaled by 100). Estimated coefficients on the fourth row imply that compliance of the 25 board regulation decreased leverage, particularly chaebol affiliates. This negative impact of chaebol affiliate supports our previous findings described above.

\section{***** Table 7. Difference-in-difference-in-differences estimation of the effect of outsider monitoring on excess growth $* * * * *$}

Finally, we estimated after restricting the sample up to 2006 and excluding the rest to avoid noises associated with the onset of the Global Financial Crisis. In untabulated tables, our main findings are intact with this restricted sample.

\section{SUMMARY AND CONCLUSION}

Using instruments from a natural experiment associated with policy changes, we investigated the impact of the appointment of outside directors on corporate leverage, compliance of leverage regulation (i.e., regulation risk), and excessive growth combined with corporate downsizing.

Our findings show that increase in outsider monitoring leads to a decrease in leverage in Korea where most firms experienced financial distress during the 1997 financial crisis. These findings differ from those in a stable economy. Intuitively, a greater role for outside directors should reduce the costs of external financing. This is because lenders have a stronger incentive to provide capital to firms as default/bankruptcy risk reduces as a result of improved monitoring of risk management by outside directors. This lender's channel effect, coupled with the pecking order theory of financing, implies improved governance can 
increase leverage. However, our instrumental estimations illustrate that outside directors' monitoring of firms that experienced substantial changes in the corporate governance system following the financial crisis considers both the positive effects of financing costs and the negative effects of increased bankruptcy risks. The net effect of outsider monitoring on leverage, after controlling for the regulation effects, is negative during our sample period. This negative effect was statistically significant for chaebol affiliates but not for nonchaebols. This finding implies the increased board's awareness of leverage risks for chaebols. Our instrumental variable Probit estimation also implies that monitoring by outside directors increases a firm's compliance with the leverage regulations, particularly for chaebols.

A further analysis indicates that the positive effect of leverage on excessive growth strategy and excessive investment is consistently observed for chaebol affiliates, particularly for top 10 largest chaebols. Theory indicates that only real variables directly affect firm value. We interpret the negative effect of outsider monitoring on excessive growth strategy and excessive investment following the crisis and financial distress was positively evaluated by market investors which in turn explains why existing studies report positive association of outside directors with firm value.

An implication of our finding to corporate governance theory is that the effect of improved governance on capital structure could be nonlinear depending on the relative weights for the lender's and borrower's channels. The agency theory indicates a positive effect of improved corporate governance and monitoring on value of a firm. Our findings also add value to this existing theory by illustrating that improved governance affects corporate strategic choices such as risk managements and economic variables like growth and investment which are crucial to determine value of a firm. Results in this paper further illustrate that chaebols, 
particularly large chaebols, were more flexible than non-chaebols in adjusting the borrower's channels.

Due largely to space problems, our analysis did not include the effect of characteristics of board members. For example, gender diversity or diversity in age and different experience of the appointed outside directors may play a role differently in our research framework. This could be a next project to examine as an extension of the current paper. ${ }^{9}$ While there could be other factors pertinent to interlocking boards, or a role of the number of board memberships ('busyness' - busy board members negatively affect value), our paper did not cover these issues because of the absence of the data. We admit that the instrument variable method is the work-horse to handle the endogeneity problem (Wooldridge, 2010) but it is challenging to find valid excluded instruments (Roberts and Whited, 2011). We introduced a natural experiment to find the valid excluded instrument which is different from the popularly used lagged variables or subjectively selected variables. Though not necessarily perfect, obtaining excluded instruments from a natural experiment is one of the advanced methods to avoid subjectiveness of the selection of valid instruments (Angrist and Pischke, 2009). Our main findings passed a number of robustness checks.

\section{REFERENCES}

Ahern, K., \& Dittmar, A.K., (2012). The changing of the boards: The impact on firm valuation of mandated female board representation, Quarterly Journal of Economics, 127: 137-197.

Ahn, S-Y., \& Park, D-J., (2016). Corporate social responsibility and corporate longevity: The mediating role of social capital and moral legitimacy in Korea, Journal of Business Ethics, forthcoming.

American Law Institute, (1994), Principles of Corporate Governance: Analysis and Recommendation Vol.1, Philadelphia: The American Law Institute Publishers.

\footnotetext{
${ }^{9}$ We thank an anonymous reviewer for this suggestion.
} 
Amiti, M., \& Weinstein, D.E., (2011), Exports and financial shocks, Quarterly Journal of Economics, 126: 1841-1877.

Angrist, J.D., \& Pischke, J-S, (2009), Mostly harmless econometrics, Princeton University Press.

Bae, K-H, J-K. Kang \& J-M. Kim, (2002), Tunnelling or value added? Evidence from mergers by Korean business groups, Journal of Finance 57(6): 2695-2740.

Baek, J-S., Kang, J-K., \& Park K.S., (2004), Corporate governance and firm value: evidence from the Korean financial crisis, Journal of Financial Economics, 71: 265-313.

Baysinger, B. D. \& R. E. Hoskisson, (1990), The Composition of Boards and Strategic Control: Effects on Corporate Strategy, Academy of Management Review 15: 72-87.

Bertrand, M., \& Mullainathan, S., (2003), Enjoying the quiet life? Corporate governance and managerial preference, Journal of Political Economy, 111: 1043-1075.

Billet, M.T., Garfinkel, J.A., \& Jiang, Y., (2011), The influence of governance on investment: Evidence from a hazard model, Journal of Financial Economics, 102: 643-670.

Black, B.S., \& Kim, W., (2012). The effect of board structure on firm value: a multiple identification strategies using Korean data, Journal of Financial Economics, 104: 203-226.

Blair, M. M. (1995). Ownership and control: Re-thinking corporate governance for the twenty-first century. Washington, DC: Brookings Institution Press.

Booth, L., Aivazian, V., Demirguc-Kunt, A., \& Maksimovic, V., (2001), Capital structure in developing countries, Journal of Finance, 56: 87-130.

Byrd, J.W., \& Hickman, K.A., (1992). Do outside directors monitor manager? Evidence from tender offer bids. Journal of Financial Economics, 32: 195- 221.

Chang, Y.K., Oh, W-Y., Park, J.H. \& Jang, M.G. (2015), Exploring the relationship between board characteristics and CSR: Empirical evidence from Korea, Journal of Business Ethics, DOI 10.1007/s10551-015-2651-z.

Choi, J., Park, S., \& Yoo, S., (2007). The value of outside directors: Evidence from corporate governance reform in Korea, Journal of Financial and Quantitative Analysis, 42: 941-962.

Cho, S-S, Ghoul, S. I., Guedhami, O., \& Suh, J., (2014), Creditor rights and capital structure: Evidence from international data, Journal of Corporate Finance, 25: 40-60.

Coles, J.L., Daniel, N.D., \& Naveen, L., (2008). Boards: Does one size fit all?, Journal of Financial Economics, 87: 329-356. 
Core, J.E., Holthausen, R.W., \& Larcker, D.F., (1999). Corporate governance, chief executive officer compensation, and firm performance. Journal of Financial Economics, 51: 371-406.

Cotter, J., Shivdasani, A., \& Zenner, M., (1997). Do outside directors enhance target shareholder wealth during tender offer contests? Journal of Financial Economics, 43: 195218.

Dahya, J., \& McConnell, J., (2007). Board composition, corporate performance, and the Cadbury Committee Recommendation. Journal of Financial and Quantitative Analysis, 42: 535-564.

Dalton, D., Daily, C., Johnson, J., \& Ellstrand, A., (1999). Number of directors and financial performance: a meta-analysis. Academy of Management Journal, 42: 674-686.

Dutchin, R., Matsusaka, J.G., \& Ozbas, O., (2010). When are outside directors effective?, Journal of Financial Economics, 96: 195-214.

Dybvig, P.H. \& Zender, J.F., (1991), Capital structure and dividend irrelevance with asymmetric information, Review of Financial Studies, 4: 201-220.

Easterbrook FH. (1984). Two agency-cost explanations of dividends. American Economic Review 74: 650-659.

Fama, E., \& Jensen, M., (1983). Separation of ownership and control. Journal of Law and Economics, 26: 301-325.

Giroud, X., \& Mueller, H., (2010), Does corporate governance matte in competitive industries?, Journal of Financial Economics, 95: 312-331.

Grossman, S. \& Hart, O. (1982), Corporate Financial Structure and Managerial Incentives. In J. McCall (ed.), The Economics of information and Uncertainty. Chicago: University of Chicago Press.

Harford, J., Mansi, S., \& Maxwell, W.F., (2008), Corporate governance and a firm's cash holdings, Journal of Financial Economics, 87: 535-555.

Harris, M., \& Raviv, A., (2008). A theory of board control and size. Review of Financial Studies, 21, 1797-1832.

Harris, M., \& Raviv, A., (1991), The theory of capital structure, Journal of Finance, 91: 297355.

Hermalin, B., \& Weisbach, M., (1989). The determinants of board composition. Rand Journal of Economics, 19: 589-606.

Hermalin, B., \& Weisbach, M., (1998). Endogenously chosen boards of directors and their monitoring of the CEO. American Economic Review, 88: 96-118. 
Jensen, M.C., (1986), Agency costs of free cash flow, corporate finance and takeovers, American Economic Review, 76: 323-329.

Jensen, M.C., \& Meckling, W.H., (1976), Theory of the firm: Managerial behaviour, agency costs and ownership structure, Journal of Financial Economics, 3: 305-360.

Jensen, M. C. (1993). The modern industrial revolution, exit, and the failure of internal control systems, Journal of Finance, 48: 831-880.

Joh, S.W., (2004), The Korean Economic Crisis and Corporate Governance System in Ito, T., and Krueger, A.O. (eds.) Governance, Regulation, and Privatization in the Asia-Pacific Region, NBER Conference Paper, Cambridge, Mass.: National Bureau of Economic Research.

Joh, S.W., \& Jung J-Y, (2011), A Friend in Need is a Friend Indeed: The Role of Outside Directors, Seoul National University, Working Paper, 2011, Seoul Korea.

Kawai, M., Lieberman, I., \& Mako, W.P., (2000). Approaches, Results and Lessons, in (eds.) Adams, C., Litan, R.E. and Pomerleano, M., Managing Financial and Corporate Distresses: Lessons from Asia, Brookings Institution, Washington D.C.

Kim, J., Lee, W. (2015). Issues and resolutions of outside directors system: from a perspective of board composition and their behaviours, KDI Focus, Korea Development Institute, Seoul Korea.

Kroll, M., Walters, B.A., \& Wright, P., (2008). Board vigilance, director experience and corporate outcomes, Strategic Management Journal, 29: 363-382.

Krueger, Anne O., \& Jungho Yoo. (2001). Chaebol capitalism and the currency financial crisis in Korea. NBER Conference Paper. Cambridge, Mass.: National Bureau of Economic Research, February.

Lang, L., Ofek, E. \& Stulz, R.M., (1996), Levrage, investment and firm growth, Journal of Financial Economics, 40: 3-29.

La Porta, R., Lopez-de-Silanes, F., Shleifer, A., \& Vishny, R.W., (1997), Legal determinants of external finance, Journal of Finance, 52: 1131-1150.

Lee, W-R, (2015), A Study of Board Independence and the Sensitivity of CEO Turnover to Performance, in (eds.) W-H Lim, Corporate Governance of Large Business Groups:

Empirical Assessments and Policy Implications, Korea Development Institute, Seoul Korea. pp.100-152.

Lemmon, M., Roberts, M.R., \& Zender, J., (2008), Back to the beginning: Persistence and the cross-section of corporate capital structures, Journal of Finance, 63: 1575-1608.

Li, J.S., (2003), Relation-based versus rule-based governance: An explanation of the East Asian miracle and Asian crisis, Review of International Economics 11(4): 651-673. 
Lipton, M. \& Lorsch, J. W. (1992). A modest proposal for improved corporate governance, Business Lawyer, 48: 59- 77.

Moskalev, S. \& Park, S.C. (2010), South Korean Chaebols and Value-Based Management, Journal of Business Ethics, 92:49-62.

Mclean, R.D., Zhang, T. \& Zhao, M., (2012), Why does the law matter? Investor protection and its effects on investment, finance and growth, Journal of Finance, 67: 313-350.

Min, B.S, (2013), Evaluation of board reforms: An examination of the appointment of outside directors, Journal of the Japanese and International Economies, 29: 21-43.

Min, B.S., (2016), "Reform of corporate governance: The Case of Korea”, Asian Journal of Political Science, 24(1): 21-41.

Min, B.S., \& Verhoeven, P., (2013), Outsider board activity, ownership structure and firm value: Evidence from Korea, International Review of Finance, 13: 187-214.

Min, B.S., \& Smyth, R., (2014), Corporate governance, globalisation and firm productivity, Journal of World Business, 49: 372-385.

Mitton, T., (2002), A cross-firm analysis of the impact of corporate governance on the East Asian financial crisis, Journal of Financial Economics, 64: 215-241.

Myers, S.C., (1977), Determinants of corporate borrowing, Journal of Financial Economics, 5: $147-175$.

Myers, S.C., \& N.S. Majluf, (1984), Corporate financing and investment decisions when firms have information investors do not have, Journal of Financial Economics, 13: 187-221.

Nguyen, B.D., \& Nielsen, K.M., (2010). The value of independent directors: Evidence from sudden deaths, Journal of Financial Economics, 98: 550-567.

Oh, W.Y., Chang, Y.K. \& Martynov, A. (2011). The effect of ownership structure on corporate social responsibility: Empirical evidence from Korea, Journal of Business Ethics, 104: 283-297.

OECD, (2004), Principles of Corporate Governance, Paris: OECD.

OECD, (2003), White Paper on Corporate Governance in Asia, Paris: OECD.

Rajan, R., \& Zingales, L., (1998), Which capitalism? Lessons from the East Asian crisis, Journal of Applied Corporate Finance, 11: 40-48.

Rajan, R., \& Zingales, L., (1995), What do we know about capital structure? Some evidence from international data, Journal of Finance, 64: 1657-1695.

Richardson, S., (2006), Over-investment of free cash flow, Review of Accounting Studies, 11: 159-189. 
Roberts, M.R., \& Whited, T.M., (2011), Endogeneity in empirical corporate finance, http://ssrn.com/abstract=1748604.

Rosenstein, S., \& Wyatt, J.G., (1990). Outside directors, board independence, and shareholder wealth. Journal of Financial Economics, 26: 175-191.

Shleifer, A. , \& Vishney, R.W., (1997), A survey of corporate governance, Journal of Finance, LII:737-783.

Schwartz-Ziv, M., \& Weisbach, M.S., (2013). What do boards really do? Evidence from minutes of board meetings, Journal of Financial Economics, 108: 349-366.

Song, C. \& Han, S.H., (2015). Stock market reaction to corporate crime: Evidence from South Korea, Journal of Business Ethics, DOI.10.1007/s10551-015-2717-y.

Stiglitz, J.E., (2001). Principles of financial regulation: A dynamic portfolio approach, World Bank Research Observer, 16: 1-18.

Stulz, R.M., (1990). Managerial discretion and optimal financing policies, Journal of Financial Economics, 26: 3-27.

Welch, I., (2004). Capital structure and stock returns, Journal of Political Economy, 112: 106-131.

Yermack, D. (1996). Higher market valuation of companies with a small board of directors, Journal of Financial Economics, 40: 185-221.

Yun, H., (2008), The Choice of corporate liquidity and corporate governance, Review of Financial Studies, 22: 1447-1475.

Wooldridge, J., (2010), Econometric Analysis of Cross Section and Panel Data, the MIT Press. 
TABLE 1

SUMMARY STATISTICS

\begin{tabular}{|c|c|c|c|c|c|c|c|c|c|}
\hline Variable & Definition & $\mathrm{N}$ & Mean & $\begin{array}{l}\text { Standard } \\
\text { deviation }\end{array}$ & P50 & $\max$ & $\begin{array}{l}\text { Chaebol } \\
\text { Affiliate } \\
\text { (1) }\end{array}$ & $\begin{array}{l}\begin{array}{l}\text { Non- } \\
\text { chaebol } \\
(2)\end{array} \\
\end{array}$ & $\begin{array}{l}\text { Diff. } \\
\text { (2)-(1) } \\
\text { (p-value) }\end{array}$ \\
\hline $\begin{array}{l}\text { Outsider } \\
\text { monitoring }\end{array}$ & $\begin{array}{l}\text { Outside } \\
\text { director/board } \\
\text { member }\end{array}$ & 6709 & 0.327 & 0.186 & 0.333 & 0.75 & 0.31 & 0.28 & $\begin{array}{l}-0.03^{* * *} \\
(0.00)\end{array}$ \\
\hline BOD & Board member & 6709 & 6.155 & 2.711 & 6 & 14 & 6.56 & 5.36 & $\begin{array}{l}-1.21^{* * *} \\
(0.00)\end{array}$ \\
\hline BOD1998 & $\begin{array}{l}\text { Board member } \\
\text { in } 1998\end{array}$ & 317 & 7.139 & 5.71 & 6 & 29 & 11.1 & 6.4 & $\begin{array}{l}-4.7^{* * *} \\
(0.00)\end{array}$ \\
\hline Leverage & $\begin{array}{l}\text { Total debt/ } \\
\text { Book value } \\
\text { equity }\end{array}$ & 6709 & 70.678 & 96.173 & 44.932 & 974.92 & 84.28 & 68.69 & $\begin{array}{l}-15.58^{* * *} \\
(0.00)\end{array}$ \\
\hline Growth rate & $\begin{array}{l}\text { (Total asset } \\
(\mathrm{TA})_{\mathrm{t}}-\mathrm{TA}_{\mathrm{t}-} \\
\left.\text { (.) } / \mathrm{TA}_{\mathrm{t}-1}\right) * 100\end{array}$ & 6709 & 7.243 & 23.794 & 5.880 & 592.53 & 8.53 & 8.23 & $\begin{array}{l}-0.27 \\
(0.74)\end{array}$ \\
\hline $\begin{array}{l}\text { Investment } \\
\text { growth rate }\end{array}$ & $\begin{array}{l}\text { (property+plant } \\
\text { and equipment } \\
\left.(\mathrm{PPE})_{\mathrm{t}}-\mathrm{PPE}_{\mathrm{t}-1}\right) / \\
\left.\mathrm{PPE}_{\mathrm{t}-1}\right)^{*} 100\end{array}$ & 6709 & 9.209 & 23.718 & 12.930 & 883.80 & 8.82 & 9.12 & $\begin{array}{l}0.30 \\
(0.51)\end{array}$ \\
\hline Tobin Q & $\begin{array}{l}\text { (market value of } \\
\text { equity+book } \\
\text { value } \\
\text { liability)/book } \\
\text { value of asset }\end{array}$ & 6509 & 1.01 & 0.304 & 0.995 & 8.94 & 1.01 & 0.98 & $\begin{array}{l}-0.03 * * * \\
(0.00)\end{array}$ \\
\hline Assets & $\begin{array}{l}\text { In(asset in } 1,000 \\
\text { won) }\end{array}$ & 6532 & 19.563 & 1.532 & 19.258 & 26.161 & 21.43 & 18.97 & $\begin{array}{l}-2.46 * * * \\
(0.00)\end{array}$ \\
\hline Earnings & EBIT/assets & 6532 & 0.043 & 0.076 & 0.043 & 0.613 & 0.05 & 0.04 & $\begin{array}{l}-0.01^{* * *} \\
(0.00)\end{array}$ \\
\hline Firm age & $\begin{array}{l}\text { years from } \\
\text { incorporation }\end{array}$ & 5685 & 18.64 & 11.448 & 18 & 58 & 21.51 & 16.22 & $\begin{array}{l}-5.28 * * * \\
(0.00)\end{array}$ \\
\hline Sharereturn & $\begin{array}{l}\text { Continuously } \\
\text { compounded } \\
\text { growth rate of } \\
\text { share price }\end{array}$ & 6370 & -0.024 & 0.545 & 0.019 & 3.283 & 0.02 & -0.05 & $\begin{array}{l}-0.08 * * * \\
(0.00)\end{array}$ \\
\hline $\begin{array}{l}\text { Leverage } \\
<200\end{array}$ & $\begin{array}{l}1 \text { if a firm's } \\
\text { leverage is less } \\
\text { than } 200 \% \text {, and } \\
0 \text { otherwise }\end{array}$ & 6709 & 0.906 & 0.292 & 1 & 1 & 0.82 & 0.86 & $\begin{array}{l}0.04^{* * *} \\
(0.00)\end{array}$ \\
\hline top30chaebol & $\begin{array}{l}1 \text { if a firm } \\
\text { belongs to top } \\
30 \text { chaebol, and } \\
0 \text { otherwise }\end{array}$ & 6709 & 0.171 & 0.376 & 0 & 0 & & & \\
\hline top10chaebol & $\begin{array}{l}1 \text { if a firm } \\
\text { belongs to top } \\
10 \text { chaebol, and } \\
0 \text { otherwise }\end{array}$ & 6709 & 0.084 & 0.278 & 0 & 0 & & & \\
\hline $\begin{array}{l}\text { top11 to } 30 \\
\text { chaebol }\end{array}$ & $\begin{array}{l}1 \text { if a firm } \\
\text { belongs to top } \\
11-30 \text { chaebol, } \\
\text { and } 0 \text { otherwise }\end{array}$ & 6709 & 0.087 & 0.281 & 0 & 0 & & & \\
\hline
\end{tabular}

Note: $\mathrm{N}$ refers to firm-year observations. P50 refers to median values. ${ }^{*}, * *, * * *$ refers to significance at 10,5 and 1 percent level respectively. Sample is winsorised at top and bottom 1 percent. 
TABLE2

IMPACTS OF OUTSIDE DIRECTOR MONITORING ON LEVEAGE

\begin{tabular}{|c|c|c|c|c|c|c|c|}
\hline & \multicolumn{4}{|c|}{ Unrestricted sample } & \multicolumn{3}{|c|}{ Only if leverage $<200$} \\
\hline & All & All & $\begin{array}{l}\text { Chaebol } \\
\text { affiliate }\end{array}$ & $\begin{array}{l}\begin{array}{l}\text { Non- } \\
\text { chaebol }\end{array} \\
\end{array}$ & \multicolumn{2}{|c|}{ Chaebol affiliate } & \multirow{2}{*}{$\begin{array}{l}\begin{array}{l}\text { Non- } \\
\text { chaebol }\end{array} \\
7 \\
\end{array}$} \\
\hline & 1 & 2 & 3 & 4 & 5 & 6 & \\
\hline $\begin{array}{l}\text { Outsider } \\
\text { monitoring }\end{array}$ & $\begin{array}{l}-0.018 * * \\
{[0.033]}\end{array}$ & $\begin{array}{l}-0.032 * * * \\
{[0.007]}\end{array}$ & $\begin{array}{l}-0.014 * * \\
{[0.035]}\end{array}$ & $\begin{array}{l}-0.004 \\
{[0.709]}\end{array}$ & $\begin{array}{l}-0.023 * * * \\
{[0.001]}\end{array}$ & $\begin{array}{l}-0.009 * * \\
{[0.050]}\end{array}$ & $\begin{array}{l}-0.010 \\
{[0.342]}\end{array}$ \\
\hline TobinQ & $\begin{array}{l}0.408^{* * *} \\
{[0.000]}\end{array}$ & $\begin{array}{l}0.410^{* * *} \\
{[0.000]}\end{array}$ & $\begin{array}{l}-0.213^{* *} \\
{[0.042]}\end{array}$ & $\begin{array}{l}0.506^{* * *} \\
{[0.000]}\end{array}$ & $\begin{array}{l}0.359 * * * \\
{[0.000]}\end{array}$ & $\begin{array}{l}-0.154^{*} \\
{[0.087]}\end{array}$ & $\begin{array}{l}0.448^{* * *} \\
{[0.000]}\end{array}$ \\
\hline Asset & $0.155^{* * *}$ & $0.172 * * *$ & $0.122 * * *$ & $0.129 * * *$ & $0.146 * * *$ & $0.070^{* *}$ & $0.111^{* * *}$ \\
\hline & {$[0.000]$} & {$[0.000]$} & {$[0.000]$} & {$[0.000]$} & {$[0.000]$} & {$[0.012]$} & {$[0.000]$} \\
\hline \multirow[t]{2}{*}{ Earning } & $-0.035 * * *$ & $-0.035^{* *}$ & $-0.033^{* * *}$ & $-0.032 * * *$ & $-0.024 * * *$ & $-0.023^{* * *}$ & $-0.023 * * *$ \\
\hline & {$[0.000]$} & {$[0.000]$} & {$[0.000]$} & {$[0.000]$} & {$[0.000]$} & {$[0.000]$} & {$[0.000]$} \\
\hline \multirow[t]{2}{*}{ Firm age } & $-0.003^{*}$ & -0.002 & -0.004 & -0.002 & $-0.003^{*}$ & $-0.009 * * *$ & -0.002 \\
\hline & {$[0.062]$} & {$[0.395]$} & [0.167] & [0.169] & {$[0.066]$} & {$[0.001]$} & {$[0.275]$} \\
\hline \multirow[t]{2}{*}{ _cons } & $-2.350 * * *$ & $-2.588 * * *$ & $-1.953 * * *$ & $-2.835 * * *$ & $-1.840 * * *$ & $-1.074 *$ & $-1.854 * * *$ \\
\hline & {$[0.000]$} & {$[0.000]$} & {$[0.002]$} & {$[0.002]$} & \multirow{2}{*}{$\begin{array}{l}{[0.000]} \\
\mathrm{Y}\end{array}$} & {$[0.050]$} & {$[0.001]$} \\
\hline Industry effect & $\mathrm{Y}$ & $\mathrm{Y}$ & Y & Y & & $\mathrm{Y}$ & $\mathrm{Y}$ \\
\hline Year effect & $\mathrm{Y}$ & $\mathrm{Y}$ & $\mathrm{Y}$ & $\mathrm{Y}$ & $\mathrm{Y}$ & $\mathrm{Y}$ & $\mathrm{Y}$ \\
\hline $\mathrm{N}$ & 5360 & 5360 & 859 & 4501 & \multirow{2}{*}{$\begin{array}{l}5001 \\
0.118\end{array}$} & 787 & 4214 \\
\hline $\bar{R}^{2}$ & 0.183 & 0.069 & 0.436 & 0.231 & & 0.433 & 0.208 \\
\hline \multicolumn{8}{|l|}{$\begin{array}{l}\text { First-Stage } \\
\text { information }\end{array}$} \\
\hline \multicolumn{8}{|l|}{$\begin{array}{l}\text { Excluded } \\
\text { instruments }\end{array}$} \\
\hline $\begin{array}{l}\text { (1):Baseline } \\
\text { BODxYear } \\
\text { (2):(Baseline } \\
\text { BODxYear) }\end{array}$ & $\mathrm{N}$ & $\mathbf{Y}$ & $\mathrm{N}$ & $\mathrm{N}$ & $\mathrm{N}$ & $\mathrm{N}$ & $\mathrm{N}$ \\
\hline$(3):(1)+(2)$ & $\mathbf{Y}$ & $\mathrm{N}$ & $\mathbf{Y}$ & $\mathbf{Y}$ & $\mathbf{Y}$ & $\mathbf{Y}$ & $\mathbf{Y}$ \\
\hline $\bar{R}^{2} /$ partial $\bar{R}^{2}$ & $0.47 / 0.01$ & $0.47 / 0.01$ & $0.47 / 0.01$ & $0.44 / 0.01$ & $0.48 / 0.02$ & $0.66 / 0.08$ & $0.45 / 0.01$ \\
\hline $\begin{array}{l}\text { F-statistics/ } \\
\text { (P-value) }\end{array}$ & $1.73 / 0.00$ & $2.11 / 0.00$ & $2.12 / 0.00$ & $1.9 / 0.00$ & $2.13 / 0.00$ & $1.98 / 0.00$ & $1.95 / 0.00$ \\
\hline
\end{tabular}

Note: The dependent variable (DV) is leverage in logarithm. All independent variables are one lagged. Figures in [ ] are cluster-robust p-values at firm level. Baseline board refers to board size in 1998. *, **, and *** refers to statistical significance at 10, 5 and 1 percent respectively. 
TABLE 3

EFFECTS OF OUTSIDER MONITORING ON COMPLIANCE WITH THE 200 LEVERAGE REGULATIONS

\begin{tabular}{|c|c|c|c|c|c|c|c|c|c|}
\hline & All & $\begin{array}{l}\text { Chaebol } \\
\text { affiliate }\end{array}$ & $\begin{array}{l}\begin{array}{l}\text { Non- } \\
\text { chaebol }\end{array} \\
\end{array}$ & All & $\begin{array}{l}\text { Chaebol } \\
\text { affiliate }\end{array}$ & $\begin{array}{l}\text { Non- } \\
\text { chaebol }\end{array}$ & All & $\begin{array}{l}\text { Chaebol } \\
\text { affiliate }\end{array}$ & $\begin{array}{l}\begin{array}{l}\text { Non- } \\
\text { chaebol }\end{array} \\
\end{array}$ \\
\hline & $Y_{97 / 01}$ & $Y_{97 / 01}$ & $Y_{97 / 01}$ & $Y_{97 / 02}$ & $Y_{97 / 02}$ & $Y_{97 / 02}$ & $Y_{97 / 03}$ & $Y_{97 / 03}$ & $Y_{97 / 03}$ \\
\hline & 1 & 2 & 3 & 4 & 5 & 6 & 7 & 8 & 9 \\
\hline \multirow[t]{2}{*}{$\begin{array}{l}\text { Outsider } \\
\text { monitoring }\end{array}$} & $0.545^{* * *}$ & $0.520 * * *$ & $-0.756 * * *$ & $0.553^{* * *}$ & $0.575^{* * *}$ & $-0.758 * * *$ & $0.396 * * *$ & $0.416^{* *}$ & $-0.756 * * *$ \\
\hline & {$[0.000]$} & {$[0.000]$} & {$[0.000]$} & {$[0.000]$} & {$[0.000]$} & {$[0.000]$} & {$[0.000]$} & {$[0.014]$} & {$[0.000]$} \\
\hline \multirow[t]{2}{*}{ TobinQ } & $-0.299 * * *$ & -0.255 & 0.011 & $-0.337 * * *$ & $-0.323^{*}$ & 0.021 & $-0.431 * * *$ & $-0.354^{*}$ & 0.020 \\
\hline & {$[0.000]$} & [0.116] & [0.555] & {$[0.000]$} & [0.057] & {$[0.751]$} & {$[0.000]$} & {$[0.066]$} & {$[0.752]$} \\
\hline \multirow[t]{2}{*}{ Asset } & $-0.197 * * *$ & 0.012 & $0.055^{* * *}$ & $-0.151 * *$ & $-0.114 * * *$ & $0.061 * * *$ & $-0.130 * * *$ & -0.010 & $0.062 * * *$ \\
\hline & {$[0.000]$} & [0.523] & {$[0.001]$} & {$[0.000]$} & [0.009] & {$[0.000]$} & {$[0.000]$} & [0.575] & {$[0.000]$} \\
\hline \multirow[t]{2}{*}{ Earning } & $0.157^{* * *}$ & $0.459 * * *$ & 0.019 & $0.173^{* * *}$ & $0.326 * * *$ & 0.144 & $0.172 * * *$ & $0.326 * * *$ & 0.141 \\
\hline & {$[0.000]$} & {$[0.000]$} & [0.332] & {$[0.000]$} & {$[0.000]$} & [0.464] & {$[0.000]$} & {$[0.000]$} & [0.454] \\
\hline \multirow[t]{2}{*}{ Firm age } & $0.028 * * *$ & $0.051^{* * *}$ & $0.008 * * *$ & $0.030 * * *$ & $0.054^{* * *}$ & $0.007 * * *$ & $0.042 * * *$ & $0.066^{* * *}$ & $0.007 * * *$ \\
\hline & {$[0.000]$} & {$[0.000]$} & {$[0.000]$} & {$[0.000]$} & {$[0.000]$} & {$[0.000]$} & {$[0.000]$} & {$[0.000]$} & {$[0.001]$} \\
\hline \multirow[t]{2}{*}{ _cons } & $3.774 * * *$ & $-4.08 * * *$ & $2.029 * * *$ & $3.514^{* * *}$ & $-1.492^{*}$ & $1.575^{* * *}$ & $2.956 * * *$ & $-3.020 * * *$ & $1.544 * * *$ \\
\hline & [0.000] & [0.000] & {$[0.000]$} & [0.000] & [0.065] & {$[0.000]$} & [0.000] & [0.001] & {$[0.000]$} \\
\hline \multicolumn{10}{|l|}{$\begin{array}{l}\text { First-stage } \\
\text { estimation }\end{array}$} \\
\hline \multirow{3}{*}{$\begin{array}{l}\text { Year fixed effect } \\
\rho\end{array}$} & Y & Y & Y & Y & Y & $Y$ & Y & Y & Y \\
\hline & $-0.23 * * *$ & $-0.61 * *$ & $3.75^{* * *}$ & $-0.23 * * *$ & $-0.62 * * *$ & $4.534 * * *$ & $-0.57^{* *}$ & -0.21 & $4.382 * * *$ \\
\hline & {$[0.000]$} & [0.012] & {$[0.000]$} & {$[0.000]$} & [0.002] & {$[0.000]$} & [0.015] & [0.471] & {$[0.000]$} \\
\hline$N$ & 5427 & 864 & 4563 & 5427 & 864 & 4563 & 5427 & 864 & 4563 \\
\hline II & 348.8 & -7.88 & 610.43 & 479.53 & 15.61 & 715.42 & 661.21 & 68.84 & 782.75 \\
\hline
\end{tabular}

Note: Instrumental variables Probit estimation of the monitoring effect of outside directors on a firm's compliance with the leverage regulation. $Y_{97 / 01}$ represents a binary variable that equals one if a firm's leverage was higher than 200 in 1997 but dropped in 2001. The same method is applied to calculate the rest of the response variables. $\rho$ refers to the correlation between residuals in the structural equation (1) and the reducedform equation (2). Figures in [ ] are cluster-robust p-values at firm-level. For brevity purpose, we reported only excluded instruments in the first-stage estimation at lower panel. *, **, *** refers to significant at 10, 5 and 1 percent level. 
TABLE 4

\section{IMPACT OF OTUSIDER MONITORING ON EXCESS GROWTH}

\begin{tabular}{|c|c|c|c|}
\hline & All & Chaebol affiliate & Non-chaebol \\
\hline & 1 & 2 & 3 \\
\hline \multirow[t]{2}{*}{ Outsider monitoring } & $-0.250 * *$ & $-0.666^{* *}$ & -0.092 \\
\hline & {$[0.045]$} & {$[0.037]$} & [0.825] \\
\hline \multirow[t]{2}{*}{ TobinQ } & $0.527 * * *$ & $0.167 * * *$ & 0.025 \\
\hline & {$[0.001]$} & {$[0.000]$} & {$[0.121]$} \\
\hline \multirow[t]{2}{*}{ Asset } & $-0.125^{* * *}$ & 0.217 & $-0.323 * * *$ \\
\hline & {$[0.009]$} & [0.215] & {$[0.000]$} \\
\hline \multirow[t]{2}{*}{ Earning } & $0.421 * * *$ & 0.271 & $0.433 * * *$ \\
\hline & {$[0.000]$} & {$[0.172]$} & {$[0.000]$} \\
\hline \multirow[t]{2}{*}{ Firm age } & 0.014 & $0.322 * *$ & -0.040 \\
\hline & {$[0.788]$} & {$[0.031]$} & {$[0.480]$} \\
\hline \multirow[t]{2}{*}{ _cons } & $54.04 * *$ & -22.15 & $69.37 * * *$ \\
\hline & {$[0.031]$} & [0.437] & {$[0.000]$} \\
\hline Industry effect & $\mathrm{Y}$ & $\mathrm{Y}$ & $\mathrm{Y}$ \\
\hline Year effect & $\mathrm{Y}$ & $\mathrm{Y}$ & $\mathrm{Y}$ \\
\hline $\mathrm{N}$ & 4494 & 794 & 4200 \\
\hline $\bar{R}^{2}$ & 0.045 & 0.038 & 0.074 \\
\hline
\end{tabular}

First-Stage

information

Excluded instruments

:Baseline BODxYear

+ (Baseline

\begin{tabular}{llll}
${\text { BODxYear })^{2}}^{2}$ & $\mathrm{Y}$ & $\mathrm{Y}$ & $\mathrm{Y}$ \\
\hline $\bar{R}^{2} /$ partial $\bar{R}^{2}$ & $0.45 / 0.01$ & $0.59 / 0.04$ & $0.44 / 0.01$
\end{tabular}

F-statistics/

(P-value) $\quad 2.02 / 0.00 \quad 2.12 / 0.00 \quad 2.15 / 0.00$

Note: Dependent variable (excessive growth in assets) is measured by 3-digit Korean SIC industry demeaned growth rate. Figures in [ ] are cluster-robust p-values at firm level. *, **, and *** refers to statistical significance at 10, 5 and 1 percent respectively. 
TABLE 5

EFFECT OF OUTSIDER MONITORING ON EXCESS INVESTMENT

\begin{tabular}{|c|c|c|c|}
\hline & All & $\begin{array}{l}\text { Chaebol } \\
\text { affiliate }\end{array}$ & Non-chaebol \\
\hline & 1 & 2 & 3 \\
\hline \multirow{2}{*}{ Outsider monitoring } & $-0.235^{*}$ & $-0.145 *$ & -0.124 \\
\hline & {$[0.055]$} & {$[0.090]$} & {$[0.464]$} \\
\hline \multirow[t]{2}{*}{ TobinQ } & $-0.141 * *$ & $-0.613 * * *$ & -0.050 \\
\hline & {$[0.033]$} & {$[0.000]$} & {$[0.496]$} \\
\hline \multirow[t]{2}{*}{ Asset } & $-0.055 * *$ & 0.022 & $-0.105 * * *$ \\
\hline & {$[0.013]$} & {$[0.654]$} & {$[0.000]$} \\
\hline \multirow[t]{2}{*}{ Earning } & 0.271 & 0.613 & 0.194 \\
\hline & {$[0.552]$} & {$[0.341]$} & {$[0.694]$} \\
\hline \multirow[t]{2}{*}{ Firm age } & 0.002 & -0.001 & $0.004^{*}$ \\
\hline & {$[0.344]$} & {$[0.837]$} & {$[0.096]$} \\
\hline \multirow{2}{*}{ _cons } & $2.040 * *$ & -0.070 & $1.533 * *$ \\
\hline & {$[0.037]$} & {$[0.951]$} & {$[0.050]$} \\
\hline Industry effect & $\mathrm{Y}$ & $\mathrm{Y}$ & $\mathrm{Y}$ \\
\hline Year effect & $\mathrm{Y}$ & $\mathrm{Y}$ & $\mathrm{Y}$ \\
\hline $\mathrm{N}$ & 4690 & 786 & 3904 \\
\hline $\bar{R}^{2}$ & 0.034 & 0.046 & 0.024 \\
\hline
\end{tabular}

First-Stage information

Excluded instruments

:Baseline BODxYear

$+($ Baseline

BODxYear $)^{2}$

$\bar{R}^{2} /$ partial $\bar{R}^{2}$

$\mathrm{Y}$

$\mathrm{Y}$

$\mathrm{Y}$

F-statistics/

$0.48 / 0.01 \quad 0.67 / 0.07 \quad 0.46 / 0.01$

(P-value)

$1.41 / 0.06$

$1.79 / 0.00$

$1.68 / 0.00$

Note: Investment growth is calculated by change in log of investment, calculated by adding property and plant and equipment (PPE). Excess values refer to 3KSIC mean-adjusted values. 
TABLE 6

INTRA-BUSINESS GROUP DIFFERENCE OF THE EFFECT OF OUTSIDER MONITORING ON LEVERAGE

\begin{tabular}{|c|c|c|c|c|c|}
\hline & \multicolumn{3}{|c|}{ Unrestricted chaebol } & \multicolumn{2}{|c|}{ Only if leverage $<200$} \\
\hline & $\begin{array}{l}\text { All } \\
\text { chaebol }\end{array}$ & $\begin{array}{l}\text { Top 10 } \\
\text { largest } \\
\text { chaebol } \\
\end{array}$ & $\begin{array}{l}\text { Top 11-30 } \\
\text { largest } \\
\text { chaebol }\end{array}$ & $\begin{array}{l}\text { Top 10 } \\
\text { largest } \\
\text { chaebol } \\
\end{array}$ & $\begin{array}{l}\text { Top 11-30 } \\
\text { largest } \\
\text { chaebol }\end{array}$ \\
\hline & 1 & 2 & 3 & 4 & 5 \\
\hline $\begin{array}{l}\text { Outsider } \\
\text { monitoring }\end{array}$ & $\begin{array}{l}-0.014 * * \\
{[0.035]}\end{array}$ & $\begin{array}{l}-0.161^{* * *} \\
{[0.003]}\end{array}$ & $\begin{array}{l}-0.605 \\
{[0.313]}\end{array}$ & $\begin{array}{l}-0.158^{* * *} \\
{[0.001]}\end{array}$ & $\begin{array}{l}-1.119 \\
{[0.302]}\end{array}$ \\
\hline TobinQ & $\begin{array}{l}-0.213^{* *} \\
{[0.042]}\end{array}$ & $\begin{array}{l}0.030 \\
{[0.875]}\end{array}$ & $\begin{array}{l}-0.057 \\
{[0.684]}\end{array}$ & $\begin{array}{l}-0.037 \\
{[0.825]}\end{array}$ & $\begin{array}{l}0.022 \\
{[0.851]}\end{array}$ \\
\hline Asset & $\begin{array}{l}0.122 * * * \\
{[0.000]}\end{array}$ & $\begin{array}{l}0.093^{* * *} \\
{[0.000]}\end{array}$ & $\begin{array}{l}0.353^{* * *} \\
{[0.000]}\end{array}$ & $\begin{array}{l}0.126^{* * *} \\
{[0.000]}\end{array}$ & $\begin{array}{l}0.270 * * * \\
{[0.000]}\end{array}$ \\
\hline Earning & $\begin{array}{l}-0.033 * * * \\
{[0.000]}\end{array}$ & $\begin{array}{l}-0.045^{* *} \\
{[0.000]}\end{array}$ & $\begin{array}{l}-0.049 \\
{[0.000]}\end{array}$ & $\begin{array}{l}-0.042 * * * \\
{[0.000]}\end{array}$ & $\begin{array}{l}0.023 * * * \\
{[0.003]}\end{array}$ \\
\hline Firm age & $\begin{array}{l}-0.004 \\
{[0.167]}\end{array}$ & $\begin{array}{l}-0.018 * * * \\
{[0.000]}\end{array}$ & $\begin{array}{l}-0.013^{* * *} \\
{[0.008]}\end{array}$ & $\begin{array}{l}-0.020 * * * \\
{[0.000]}\end{array}$ & $\begin{array}{l}-0.019 * * * \\
{[0.000]}\end{array}$ \\
\hline _cons & $\begin{array}{l}-1.953 * * * \\
{[0.002]}\end{array}$ & $\begin{array}{l}0.848 * * * \\
{[0.000]}\end{array}$ & $\begin{array}{l}2.062 * * \\
{[0.013]}\end{array}$ & $\begin{array}{l}0.592 * * * \\
{[0.000]}\end{array}$ & $\begin{array}{l}1.583^{*} \\
{[0.076]}\end{array}$ \\
\hline Industry effect & $\mathrm{Y}$ & $\mathrm{Y}$ & $\mathrm{Y}$ & $\mathrm{Y}$ & $\mathrm{Y}$ \\
\hline Year effect & $\mathrm{Y}$ & $\mathrm{Y}$ & $\mathrm{Y}$ & $\mathrm{Y}$ & $\mathrm{Y}$ \\
\hline $\mathrm{N}$ & 859 & 396 & 269 & 382 & 405 \\
\hline $\bar{R}^{2}$ & 0.436 & 0.212 & 0.183 & 0.261 & 0.151 \\
\hline $\begin{array}{l}\text { First-Stage } \\
\text { information }\end{array}$ & & & & & \\
\hline $\begin{array}{l}\text { Excluded } \\
\text { instruments } \\
\text { :Baseline } \\
\text { BODxYear } \\
+ \text { (Baseline } \\
\text { BODxYear) }\end{array}$ & Y & Y & Y & $\mathrm{Y}$ & $\mathrm{Y}$ \\
\hline $\begin{array}{l}\bar{R}^{2} / \text { partial } \bar{R}^{2} \\
\text { F-statistics/ } \\
\text { (P-value) }\end{array}$ & $0.47 / 0.01$ & $0.62 / 0.17$ & $0.59 / 0.08$ & $0.63 / 0.19$ & $0.57 / 0.07$ \\
\hline
\end{tabular}

Note: Dependent variable is leverage. All chaebol refers to every business groups belong to top 30 largest.

Figures in [ ] are cluster-robust p-values at firm level. *, **, and *** refers to statistical significance at 10, 5 and 1 percent respectively. 
TABLE 7

DIFFERENCE-IN-DIFFERENCE-IN-DIFFERENCES ESTIMATION OF THE EFFECT OF OUTSIDER MONIROTING ON EXCESS GROWTH

\begin{tabular}{|c|c|c|c|}
\hline & $\begin{array}{r}\text { Unrestricted } \\
\text { sample } \\
\end{array}$ & $\begin{array}{r}\text { Chaebol } \\
\text { affiliate }\end{array}$ & $\begin{array}{r}\text { Non- } \\
\text { chaebol }\end{array}$ \\
\hline & 1 & 2 & 3 \\
\hline \multirow[t]{2}{*}{ T(outsider)Xafter } & 0.0318 & 0.0428 & -0.00123 \\
\hline & [0.546] & {$[0.674]$} & [0.985] \\
\hline \multirow[t]{2}{*}{ T(outsider) } & $-0.973 *$ & -0.7406 & -0.6039 \\
\hline & {$[0.066]$} & {$[0.418]$} & [0.335] \\
\hline \multirow[t]{2}{*}{ T(outsider)XT(leverage) } & 0.6479 & $2.334 * *$ & 0.0696 \\
\hline & {$[0.161]$} & [0.02] & [0.521] \\
\hline \multirow[t]{2}{*}{ T(outsider)XT(leverage)Xafter } & -0.5642 & $-2.318 * *$ & 0.0647 \\
\hline & {$[0.231]$} & {$[0.021]$} & {$[0.565]$} \\
\hline \multirow[t]{2}{*}{$\mathrm{T}$ (leverage)Xafter } & $-0.057 * * *$ & -0.0606 & $-0.071^{* *}$ \\
\hline & [0.008] & [0.208] & [0.012] \\
\hline \multirow[t]{2}{*}{$\mathrm{T}($ leverage) } & -0.0123 & 0.0191 & -0.0182 \\
\hline & {$[0.485]$} & [0.592] & {$[0.381]$} \\
\hline \multirow[t]{2}{*}{ after } & -0.00513 & 0.0366 & -0.0080 \\
\hline & [0.423] & {$[0.463]$} & {$[0.176]$} \\
\hline \multirow[t]{2}{*}{ TobinQ } & $0.104 * * *$ & 0.0281 & $0.084 * * *$ \\
\hline & [0.00] & [0.656] & [0.002] \\
\hline \multirow[t]{2}{*}{ Asset } & $0.816^{* * *}$ & $0.989 * * *$ & $0.741^{* * *}$ \\
\hline & [0.00] & [0.00] & [0.00] \\
\hline \multirow[t]{2}{*}{ Earning } & $0.646 * * *$ & $1.0748 *$ & $0.773 * * *$ \\
\hline & {$[0.00]$} & [0.095] & [0.00] \\
\hline \multirow[t]{2}{*}{ Firm age } & $-0.001 * * *$ & 0.0007 & $-0.002 * * *$ \\
\hline & {$[0.00]$} & [0.424] & [0.00] \\
\hline \multirow[t]{2}{*}{ _cons } & $-0.207 * * *$ & $-0.122^{* *}$ & $-0.0136^{* *}$ \\
\hline & {$[0.00]$} & [0.003] & [0.007] \\
\hline $\bar{R}^{2}$ & 0.51 & 0.75 & 0.482 \\
\hline $\mathrm{N}$ & 1222 & 128 & 1094 \\
\hline
\end{tabular}

Note: T(outsider) and T(leverage) refers to a binary variable respectively equals to 1 if a firm complied with the 25 percent board regulation and the 200 percent leverage regulation and zero otherwise. After is a binary variable if time belongs to 2000-2003 and zero otherwise. T(outsider)Xafter refers to an interaction variable between $\mathrm{T}$ (outsider) and after. $\mathrm{T}$ (leverage)Xafter and $\mathrm{T}$ (leverage)XT(outsider) are similarly defined. $\mathrm{T}$ (outsider)XT(leverage)Xafter (scaled by 100) refers to a triple interaction variable. 


\section{APPENDIX 1}

PORTION OF FIRMS COMPLIED WITH THE 200 PERCENT LEVERAGE REGULATION

\begin{tabular}{ccccc}
\hline Year & $\begin{array}{c}\text { N of listed } \\
\text { firms }\end{array}$ & $\begin{array}{c}\text { Portion of firms whose leverage } \\
\text { dropped from above/equal-to 200\% in } \\
1997 \text { to below 200\% in the year }\end{array}$ & $\begin{array}{c}\text { Marginal } \\
\text { increase in } \\
\text { column (2) } \\
(1)\end{array}$ & $\begin{array}{c}\text { Standard } \\
\text { deviation of } \\
\text { column (2) }\end{array}$ \\
\hline 2001 & 633 & 0.172 & n.a. & 0.378 \\
2002 & 650 & 0.187 & 0.014 & 0.390 \\
2003 & 656 & 0.200 & 0.013 & 0.400 \\
2004 & 663 & 0.207 & 0.002 & 0.405 \\
2005 & 671 & 0.209 & 0.002 & 0.406 \\
2006 & 683 & 0.214 & 0.005 & 0.410 \\
\hline
\end{tabular}

